\title{
STUDI HABITAT DAN SUMBER PAKAN LEBAH KELULUT DI KAWASAN CAGAR ALAM GUNUNG NYIUT DESA PISAK KABUPATEN BENGKAYANG
}

(Study of The Habitat and Food Sources Kelulut Bees in the Area of Gunung Nyiut Nature Reserve at Pisak Village Bengkayang District)

\section{Vihenky Sanjaya, Dwi Astiani, Lolyta Sisillia}

Fakultas Kehutanan Universitas Tanjungpura, Jl. Daya Nasional Pontianak, 78124 e-mail: vihenky.13@gmail.com

\begin{abstract}
Kelulut Bees is a stingless bee that produces honey, in the area of Gunung Nyiut Nature Reserve Kelulut Bees lives naturally with nests on tree trunks. It is not yet known how the habitat and sources of feed so that it is necessary to do research on the study of habitat and feed sources of Kelulut Bees. This study aims to obtain information about the condition of habitat and feed sources of Kelulut Bees. The method used was a survey with double plots which purposively placed, then identified the condition of habitat and feed sources. Types of hornet bees found were: Heterotrigona itama, Tetragonula laeviceps, Geniotrigona thoracica, Trigona carbonaria and Trigona drescheri. The bees nesting place were in living trees is (52\%), dead trees (20\%) and soil (28\%). Daily mean temperature, air humidity and light intensity were $28.81{ }^{\circ} \mathrm{C}, 83.06 \%$, and $583.76 \%$. Soil type is PMK with $\mathrm{pH} 4.4$, soil temperature $26.6 \mathrm{C}{ }^{\circ}$, soil moisture $26 \%$. Altitude \pm 360 masl. Tree analysis was dominated by Xanthophyllum amoenum 36.38\%, Lepisanthes tetraphylla $38.01 \%$, Syzgium chloranthum $45.8 \%$, and Bellucia pentamera seedlings $51.58 \%$. The feed sources at the observation sites were dominated by the family Myrtaceae and Dipterocarpaceae, while outside the plots the feed source was dominated by Cocos nucifera L, Durio zibethinus, Nephelium lappaceum L, Syzygium aqueum.
\end{abstract}

Keywords : Feed source, Gunung Nyiut, habitat, kelulut bees, Nature Reserve.

\section{PENDAHULUAN}

Makhluk hidup memiliki habitat guna mendukung kehidupannya, yaitu satu kesatuan kawasan yang dapat menjamin segala keperluan hidupnya baik untuk memenuhi kebutuhan makanan, air, udara bersih, tempat berlindung, berkembang biak, maupun tempat untuk mengasuh anak-anaknya. Habitat yang sesuai bagi satu jenis makhluk hidup belum tentu sesuai untuk jenis lainnya, karena setiap jenis menghendaki kondisi habitat yang berbeda - beda (Sforcin dan Bankova, 2011).

Lebah kelulut merupakan salah satu spesies lebah penghasil madu anggota
Famili Meliponidae Genus Trigona (tidak memiliki sengat), berukuran kecil dan merupakan salah satu serangga pollinator penting (Francoy et al, 2009). Lebah jenis ini masih kurang populer dibanding dengan Famili Apidae, seperti Apis mellifera dan A. cerana. Trigona spp di Indonesia memiliki beberapa nama daerah, yaitu kelulut (Kalimantan), galogalo (Sumatera), klanceng, lenceng (Jawa), dan te'uweul (Sunda). Kelompok lebah ini membela diri dengan cara menggigit jika terganggu.

Habitat lebah kelulut banyak dijumpai di daerah tropis dan subtropis seperti di Amerika Selatan, Australia dan 
Asia Tenggara (Michener, 2007). Lebah kelulut bersarang pada pohon yang berlubang, tanah, pohon mati seta bangunan yang dimunkingkan untuk pembuatan sarang, Sarang trigona memiliki bentuk pintu masuk yang beragam, seperti berbentuk corong, bulat tidak beraturan, atau tanpa tonjolan pada pintu masuknya (Roubik, 2006). Syafrizal et al (2014) menyatakan lebah Trigona spp tergolong hewan berdarah dingin, hidupnya sangat dipengaruhi oleh suhu udara di sekitarnya, pada suhu berkisar antara $28-36^{\circ} \mathrm{C}$ dan terdapat perbedaan temperatur antara di dalam sarang dan di luar sarang.

Kawasan Cagar Alam Gunung Nyiut Desa Pisak Kabupaten Bengkayang, masyarakat sekitar masih banyak yang belum mengenal lebah kelulut. Melimpahnya lebah kelulut masih hidup secara alami di hutan, padahal lebah ini memiliki potensi yang tinggi dalam bidang ekonomi dan kesehatan, dan juga dapat menjadi alternatif pendapatan bagi masyarakat kedepannya, namun hingga saat ini lebah lebah kelulut masih belum dibudidayakan oleh masyarakat setempat. Ketiadaan informasi mengenai karakteristik habitat dan sumber pakan lebah kelulut yang terdapat di kawasan Cagar Alam Gunung Nyiut Desa Pisak yang mendasari penulis melakukan penelitian tentang studi habitat dan sumber pakan lebah kelulut.

Penelitian ini bertujuan untuk mendapatkan informasi tentang kondisi habitat dan sumber pakan dari lebah kelulut, serta diharapkan dapat memberikan informasi tentang bagaimana kondisi habitat lebah kelulut, dan tumbuhan apa saja yang menjadi sumber pakan lebah kelulut.

\section{METODOLOGI PENELITIAN}

Kegiatan penelitian ini dilaksanakan di Kawasan Cagar Alam Gunung Nyiut, Dusun Dawar, Desa Pisak, Kecamatan Tujuh Belas, Kabupaten Bengkayang. Waktu penelitian dilakukan selama satu bulan yaitu pada tanggal 4 oktober 2018 sampai dengan 4 november 2018. Pengumpulan data awal yaitu melakukan orientasi lapangan untuk pengenalan lebah kelulut. Pelaksanaan penelitian ini menggunakan metode survey yaitu kegiatan mencari keberadaan spesies yang menjadi objek penelitian lebah kelulut. Pengambilan data habitat dan sumber pakan menggunakan metode petak ganda yang diletakkan secara purposive sesuai dengan penemuan lokasi sarang dari lebah kelulut, kemudian di identifikasi kondisi habitat (iklim mikro, biologi, edafis, dan fisiografis), data sumber pakan (jenis tanaman, bagian yang dimakan), jenis lebah, jenis tempat bersarang lebah, dan karakteristik sarang lebah.

\section{HASIL DAN PEMBAHASAN}

\section{Jenis Lebah Kelulut}

Hasil pengamatan yang dilakukan di kawasan Cagar Alam Gunung Nyiut, Dusun Dawar Desa Pisak ditemukan 5 jenis lebah kelulut (Tabel 1) 
Tabel 1. Jenis Lebah Kelulut (Type of kelulut bees)

\begin{tabular}{llll}
\hline No & Nama lokal & Nama ilmiah & Famili \\
\hline 1 & Kelulut & Heterotrigona itama & Apidae \\
2 & Kelulut & Tetragonula laeviceps & Apidae \\
3 & Kelulut & Geniotrigona thoracica & Apidae \\
4 & Kelulut & Tetragonula carbonaria & Apidae \\
5 & Kelulut & Tetragonula testaceitarisis & Apidae \\
\hline
\end{tabular}

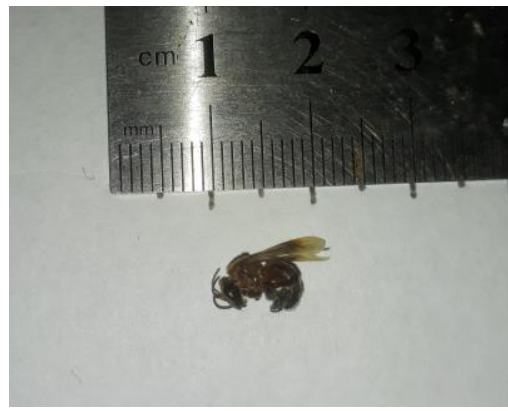

1

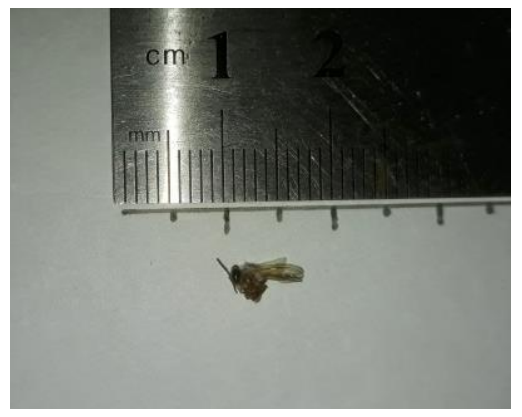

4

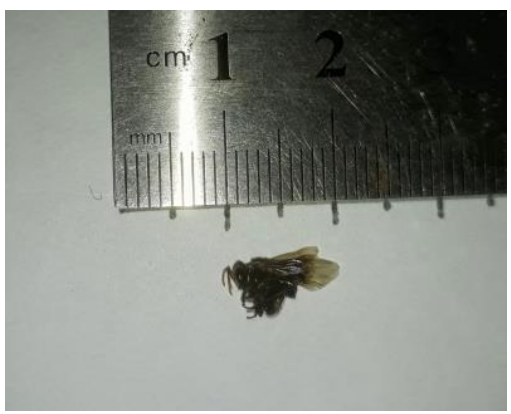

2

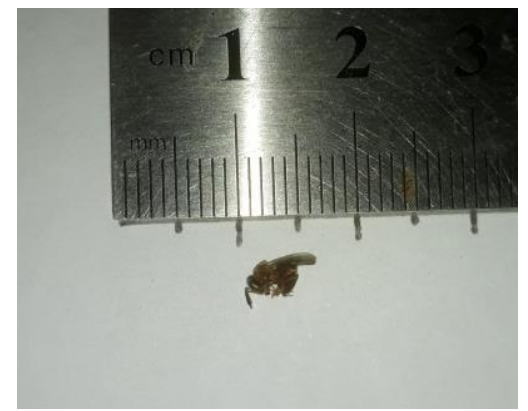

3

Gambar 1. Jenis Lebah Kelulut (Type of kelulut bees) : 1. Geniotrigona thoracica, 2. Heterotrigona itama, 3. Tetragonula carbonaria, 4. Tetragonula testaceitarisis, 5. Tetragonula laeviceps.

Jenis kelulut yang ditemukan di lokasi pengamatan yaitu Heterotrigona itama, Tetragonula laeviceps, Geniotrigona thoracica, Tetragonula carbonaria dan Tetragonula testaceitarisis family apidae. Jenis yang dominan pada lokasi penelitian ini adalah Heterotrigona itama. Heterotrigona itama merupakan lebah tak bersengat yang termasuk dalam genera heterotrigona sama seperti Geniotrigona thoracica. Setiap jenis trigona yang bergenera heterotrigona memiliki ciri yang mudah dibedakan yaitu memiliki ukuran tubuh yang lebih besar, ukuran tubuh trigona jenis ini bisa mencapai $9 \mathrm{~mm}$.

Geniotrigona thoracica merupakan jenis yang cukup spesial dibandingkan dengan jenis kelulut lainnya. Selain memiliki ukuran tubuh yang lebih besar jika dibandingkan lebah trigona lainnya, ia memiliki ciri yang mudah dibedakan pada warna tubuhnya yang didominasi 
warna hitam kecoklatan alias brownies dan bagian thorax yang berwarna coklat. Sedangkan untuk Tetragonula laeviceps merupakan jenis trigona berukuran tubuhnya standar tetapi sangat tangguh bila dibanding jenis lebah trigona lainnya. Dia mampu hidup di daerah yang miskin pakan, bahkan sering pula ditemukan hidup di wilayah yang bersuhu ekstrim. Syafrizal (2014) menyatakan bahwa ukuran tubuh sangat mempengaruhi jarak terbang lebah mencari makanan. Semakin besar tubuh lebah maka makin jauh jarak terbangnya. Trigona spp dengan ukuran $5 \mathrm{~cm}$ mempunyai jarak terbang sekitar $600 \mathrm{~m}$.

\section{Jenis Tempat Bersarang Lebah Kelulut}

Hasil pengamatan tentang tempat bersarangnya lebah kelulut didapat tiga tempat bersarang yaitu pada pohon hidup, pohon mati dan tanah. (table 2).

\section{Tabel 2. Tempat Bersarang Lebah Kelulut (Nesting place kelulut bees)}

\begin{tabular}{cccc}
\hline No & Tempat bersarang & Jumlah & Keterangan \\
\hline 1 & Pohon hidup & 13 Lubang sarang & Heterotrigona itama, Geniotrigona thoracica \\
2 & Pohon mati & 5 Lubang sarang & Heterotrigona itama \\
3 & Tanah & 7 Lubang sarang & Tetragonula laeviceps, Tetragonula \\
& & & carbonaria, Heterotrigona itama \\
\hline
\end{tabular}

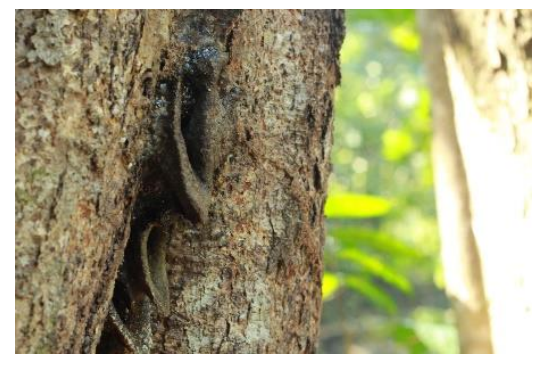

1

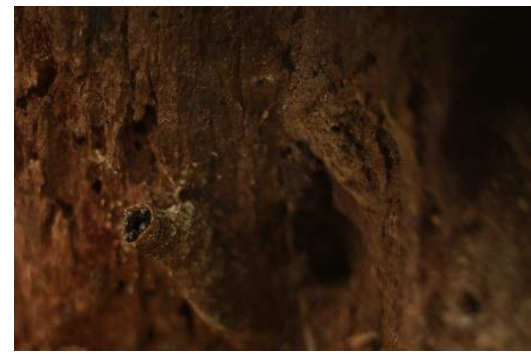

2

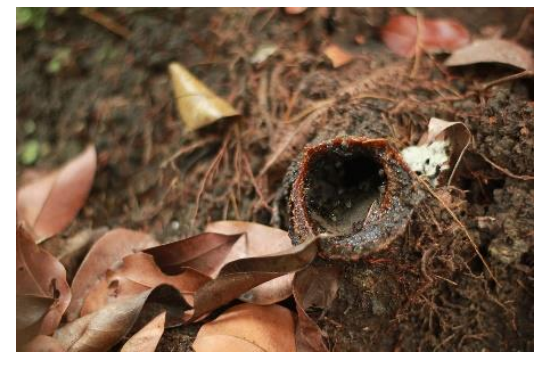

3

Gambar 2. Tempat Bersarang Lebah Kelulut (Nesting place kelulut bees) : 1. Pohon hidup (Living tree), 2. Pohon mati (Dead tree), dan 3.Tanah (Soil).

Sarang kelulut yang ditemukan pada saat pengamatan yaitu 25 sarang 13 pada pohon hidup, 5 pohon mati, dan 7 ditanah. Pada pohon hidup kelulut bersarang di batang yang berlubang, jenis pohon yang diperkirakan disukai oleh kelulut sebagai tempat bersarang adalah Xanthophyllum amoenum (Chodat) dimana jenih pohon ini banyak ditemukan dilokasi penelitian.

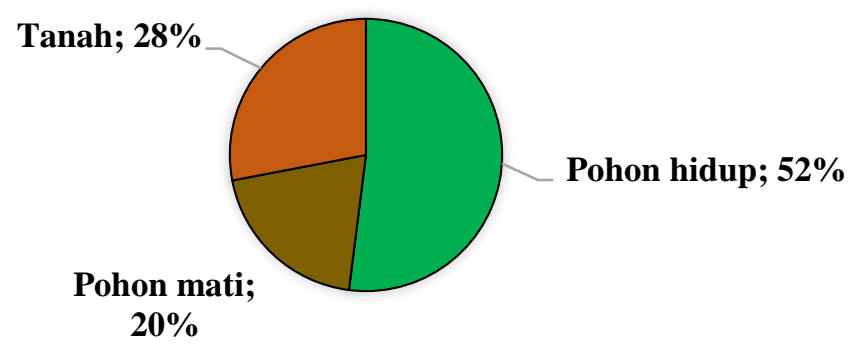

Gambar 3. Persentase Sarang Lebah Kelulut (Percentage of kelulut bees nests) 
Persentase tempat tinggal kelulut hampir setengah bersarang di pohon hidup sisanya berada di pohon mati dan tanah, hal ini membuktikan lebah kelulut lebih menyukai pohon hidup dibandingkan pohon mati dan tanah. Menurut Iqbal et al (2016) kelulut lebih senang membuat sarang pada pohon hidup yang berlubang dan berukuran besar. Trigona spp bersarang di pohon yang berukuran besar dengan diameter lebih dari $80 \mathrm{~cm}$ sebagai tempat bersarang. Hal ini diduga karena pohon yang besar memiliki tajuk yang lebih besar sehingga udara di sekitar lebih stabil. Tersedianya lingkungan mikro (microclimate) yang lebih sesuai dengan kehidupan Trigona spp terutama suhu dan kelembaban udara yang lebih stabil pada pohon besar serta tersedianya sumber pakan alami di daerah sekitarnya. Heterotrigona itama termasuk lebah yang paling mudah berkembang biak di berbagai media bersarang. Pada tabel 2 Heterotrigona itama mendominasi hampir semua tempat bersarang, sedangkan untuk Tetragonula laeviceps, Tetragonula carbonaria banyak membuat sarang di dalam tanah dan Geniotrigona thoracica hanya ditemukan bersarang pada pohon hidup.

\section{Karakteristik Sarang Lebah}

\section{Kelulut}

Hasil pengamatan tentang karakteristik sarang lebah kelulut ditemukan enam bentuk lubang sarang masuk lebah kelulut yang berbeda (gambar 4).

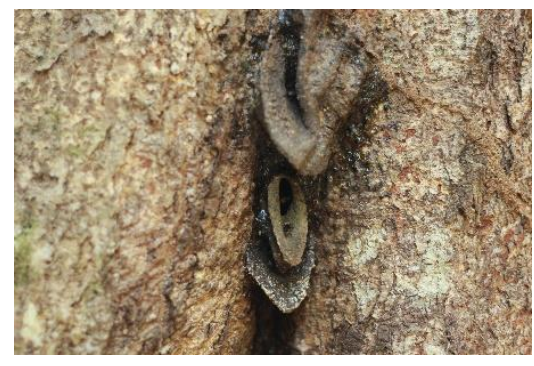

1

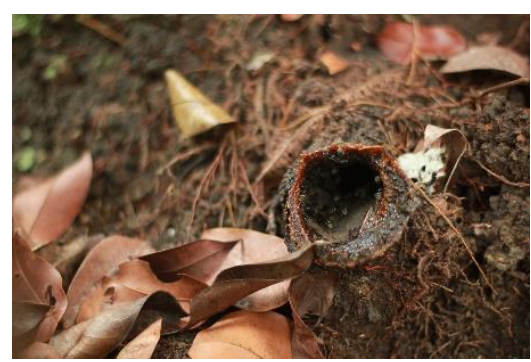

4

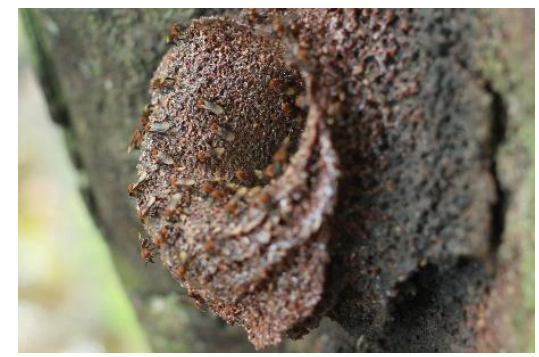

2

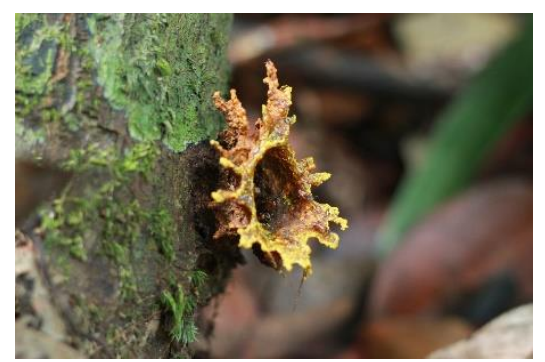

5

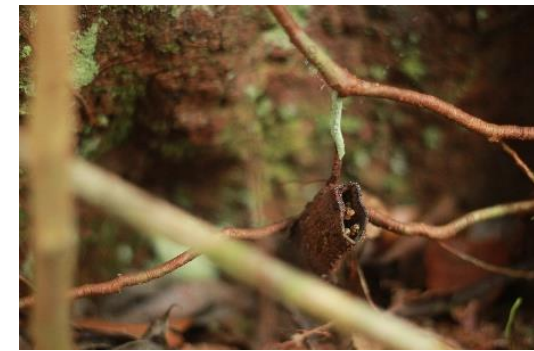

3

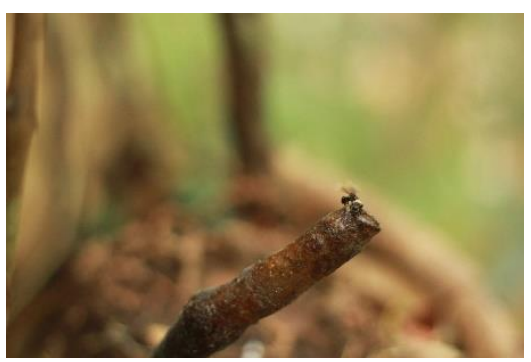

6

Gambar 4. Bentuk Lubang Sarang Lebah Kelulut (The shape of nest hole kelulut bees): 1. Heterotrigona itama, 2. Geniotrigona thoracica, 3. Tetragonula laeviceps, 4. Tetragonula carbonaria, 5. Tetragonula testaceitarisis 6. Heterotrigona itama 
Keberadaan sarang ditandai dengan bangunan unik yang berfungsi sebagai pintu masuk sarang (entrance). Pada lokasi pengamatan ditemukan enam bentuk sarang yang berbeda (gambar 4). Lubang sarang kelulut memiliki bentuk pintu masuk yang unik, seperti pada kelulut Tetragonula testaceitarisis sangat mencolok dari lubang sarang kelulut lainnya selain bentuknya yang unik lubang sarang kelulut ini juga memiliki warna pintu yang sangan mencolok kuning kemerahan. Lubang sarang kelulut Tetragonula testaceitarisis biasa juga disebut kelulut matahari karena bentuk pintu masuk kelulut ini menyerupai matahari dan ukuran lobang sarangnya yaitu $1.5 \mathrm{~cm}$.

Lubang sarang Geniotrigona thoracica juga sangat berbeda dari kelulut biasa yang ditemukan, selain ukuran sarang yang terlihat besar kelulut ini juga memiliki pintu masuk yang berukuran besar yaitu $4 \mathrm{~cm}$ hal ini disebabkan ukuran tubuh Geniotrigona thoracica yang lebih besar dari ukuran tubuh kelulut lainnya. Sedangkan untuk jenis Heterotrigona itama memiliki pintu masuk yang beragam, hal ini dikarenakan kelulut ini dapat beradaptasi dengan mudah di berbagai media tempat bersarang, ini yang menyebabkan Heterotrigona itama harus menyesuaikan pembuatan pintu sarang sesuai dengan kondisi media tempat bersarang yang berbeda.

Iqbal et al (2016) menyatakan bahwa, lebah Trigona spp hidup secara berkoloni dengan membangun sarang pada batang pohon kayu atau bambu, pilar bangunan, celah-celah bebatuan dan tanah. Pintu masuk bukan hanya untuk jalan keluar masuknya lebah tetapi juga sebagai penanda sarang, demikian pula struktur sarang lebah Trigona spp berada pada batumen-batumen yang terbuat dari campuran resin, tanah dan lumpur yang berfungsi untuk melindungi sarang jika terjadi guncangan (Michener, 2007). Sarang Trigona spp tersusun dari berbagai eksudat/resin getah pohon, campuran serbuk-serbuk kayu dan batubatuan kecil, berguna sebagai pertahanan terhadap serangan predator. Menurut Syafrizal et al (2014) menyatakan bahwa masing-masing bahan dasar penyusun sarang berbeda pada tiap jenis lebah Trigona spp dengan bentuk warna dan aroma yang dipengaruhi oleh jenis tumbuhan sumber resinnya. Ukuran tubuh lebah kelulut mempengaruhi ukuran lubang sarang lebah, semakin besar ukuran tubuh lebah semakin besar juga lubang sarangnya.

\section{Habitat Lebah Kelulut}

\subsection{Iklim Mikro}

Kondisi iklim mikro di lokasi pengamatan memiliki rerata suhu udara, kelembaban udara, dan intensitas cahaya harian sebagai berikut : 


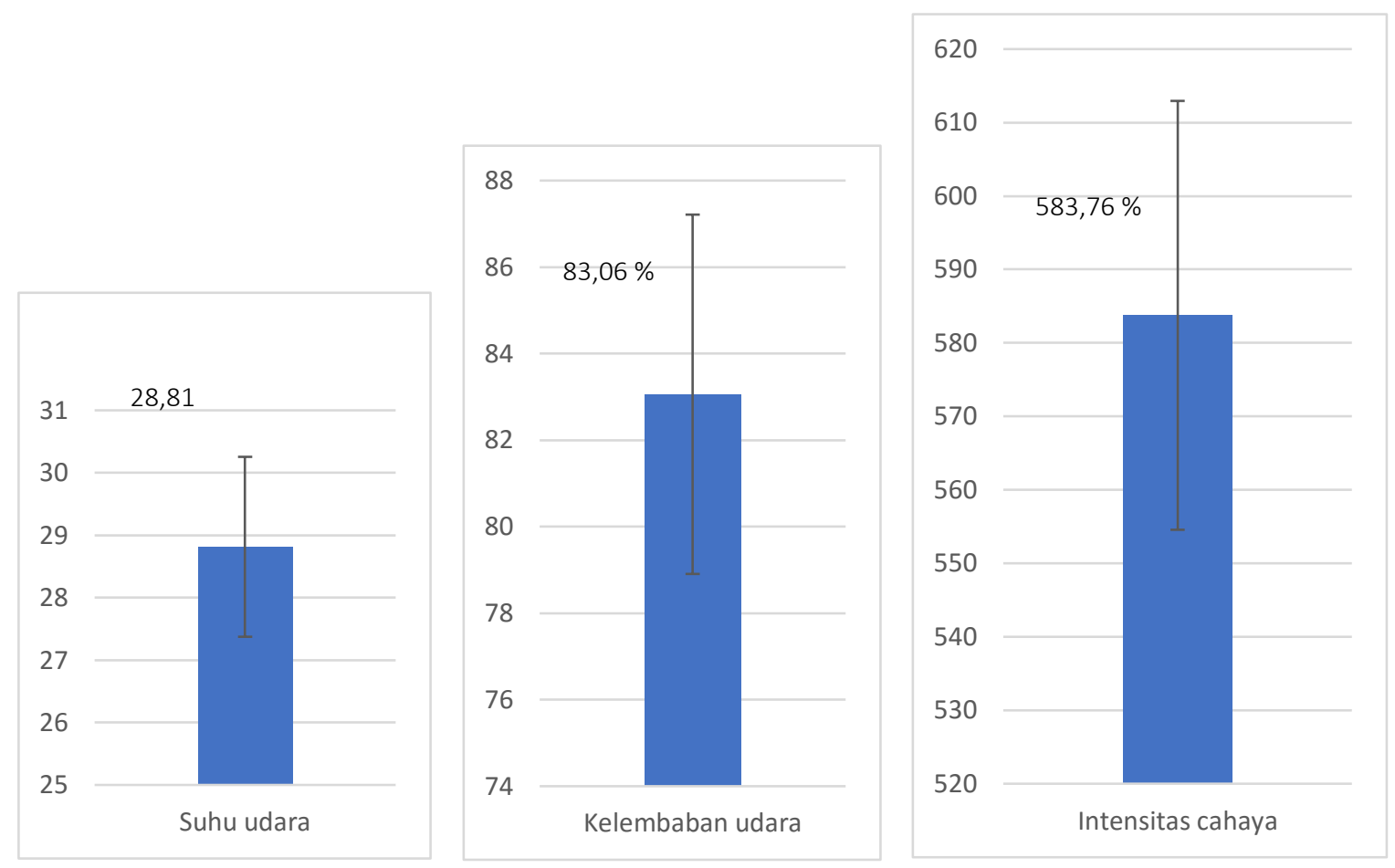

Gambar 5. Iklim Mikro (Micro climate)

Pada diagram diatas bisa dilihat suhu rerata harian pada lokasi pengamatan yaitu $28,81^{\circ} \mathrm{C}$ dengan range $27-31{ }^{\circ} \mathrm{C}$, rerata kelembaban udara $83,06 \%$ dengan range $80-85 \%$, dan intensitas cahaya $583,76 \%$ dengan range $200-1000 \%$.

Kondisi cuaca pada saat pengamatan cerah tidak mendung dan hujan, Pada suhu dan kelembaban diatas diduga kelulut di kawasan Cagar Alam Gunung Nyiut hidup dan berkembang. Syafrizal et al (2014) menyatakan lebah Trigona spp tergolong hewan berdarah dingin, hidupnya sangat dipengaruhi oleh suhu udara di sekitarnya, pada suhu berkisar antara $28-36^{\circ} \mathrm{C}$ dan terdapat perbedaan temperatur antara di dalam sarang dan di luar sarang. Pada saat pengamatan daerah sekitar sarang lebah kelulut lebih aktif berada dilubang sarang pada pagi hari dan lebih sedikit terlihat pada siang dan sore hari. Menurut Banowu (2016) Aktivitas lebah Trigona spp mulai keluar dari sarang dari pukul 05:30 sampai dengan pukul 18:19. Sebelum melakukan aktivitas, lebah madu akan berdiri didepan sarang untuk menghangatkan badannya sebelum terbang.

\subsection{Edafis}

Kondisi edafis di lokasi pengamatan untuk jenis tanah, $\mathrm{Ph}$, suhu tanah, kelembaban tanah (tabel 3) 
Tabel 3. Faktor Edafis Habitat Lebah Kelulut (Edafis factor of habitat kelulut bees)

\begin{tabular}{|c|c|c|c|c|c|}
\hline$\overline{\text { No }}$ & No Petak & Jenis Tanah & $\mathbf{P h}$ & Suhu Tanah $\left({ }^{\circ} \mathbf{C}\right)$ & Kelembaban Tanah (\% RH \\
\hline 1 & Petak 1 & PMK & 4,41 & 26 & 32 \\
\hline 2 & Petak 2 & PMK & 4,46 & 26 & 32 \\
\hline 3 & Petak 3 & PMK & 4,19 & 27 & 13 \\
\hline 4 & Petak 4 & PMK & 4,10 & 27 & 15 \\
\hline \multirow[t]{2}{*}{5} & Petak 5 & PMK & 4,80 & 25 & 45 \\
\hline & Rerata & & 4,4 & 26,6 & 27,4 \\
\hline
\end{tabular}

Berdasarkan pengamatan jenis tanah pada lokasi pengamatan diketahui jenis tanah Podsolik Merah - Kuning (PMK) yang ditentukan melalui tekstur tanah dan memiliki $\mathrm{pH}$ sebesar 4,41 - 4,80 dengan rerata semua petak 4,4 (agak asam) pada tanah yang di dekat aliran sungai yaitu berpasir. Sedangkan untuk suhu tanah antara $25 \mathrm{C}^{\circ}-27 \mathrm{C}^{\circ}$ dengan rerata $26,6 \mathrm{C}^{\circ}$, dengan rerata kelembaban tanah yaitu $27,4 \%$ RH. Kondisi Cagar Alam Gunung Nyiut sangat sesuai dengan habitat kelulut tekstur tanah yang halus ditemukan sedikit berpasir, ditumpuki serasah daun dan ranting hutan pada lapisan atas tanah. Sarang kelulut yang berada ditanah banyak ditemukan di bawah bawah pohon berdiameter besar banyak dipenuhi serasah daun dan ranting pohon sehingga lebih susah ditemukan jika dibandingkan pencarian di pohon hidup dan pohon mati.

\subsection{Fisiografis}

Faktor fisiografis pada lokasi pengamatan memiliki rerata ketinggian yang tidak jauh berbeda, pada ketinggian ini sarang kelulut banyak ditemui (tabel 4).

Tabel 4. Faktor Fisiografis Habitat Lebah Kelulut (Fisiografis factor of habitat kelulut bees)

\begin{tabular}{lcc}
\hline No & No Petak & Ketinggian Tempat \\
\hline 1 & Petak 1 & $360 \mathrm{~m} \mathrm{dpl}$ \\
2 & Petak 2 & $361 \mathrm{~m} \mathrm{dpl}$ \\
3 & Petak 3 & $361 \mathrm{~m} \mathrm{dpl}$ \\
4 & Petak 4 & $362 \mathrm{~m} \mathrm{dpl}$ \\
5 & Petak 5 & $364 \mathrm{~m} \mathrm{dpl}$ \\
\hline
\end{tabular}

Lokasi pengamatan di Kawasan Cagar Alam Gunung Nyiut terletak pada ketinggian tempat $\pm 360 \mathrm{~m} \mathrm{dpl}$, perbedaan ketinggian tempat tiap petak tidak terlalu jauh, meningkat hanya 4 meter dari petak pertama hingga petak kelima. Diduga kelulut menyukai ketinggian tempat yang tidak terlalu tinggi dikarenakan pada dataran sedang sumber pakan untuk lebah kelulut masih melimpah. Menurut Syafrizal et al (2012) menunjukkan bahwa sarang lebah Kelulut memiliki ketinggian tempat yang bervariasi yaitu berkisar antara 90 - 400 m dpl dikarenakan hidupnya sangat dipengaruhi oleh suhu udara di sekitarnya.

\subsection{Biologi}


Analisis data biologi meliputi penghitungan indeks nilai penting jenis pohon dan tumbuhan bawah dari 5 petak yang dibandingkan. Indeks nilai penting jenis tumbuhan pada suatu komunitas merupakan salah satu parameter yang menunjukkan peranan jenis tumbuhan tersebut dalam komunitasnya.

Tabel 5. Analisis Vegetasi Tingkat Pohon (Tree level vegetation analysis)

\begin{tabular}{|c|c|c|c|c|c|c|c|}
\hline No & Nama lokal & Nama ilmiah & Family & $\begin{array}{l}\text { FR } \\
(\%)\end{array}$ & $\begin{array}{l}\text { KR } \\
(\%)\end{array}$ & $\begin{array}{l}\text { DR } \\
(\%)\end{array}$ & $\begin{array}{l}\text { INP } \\
(\%)\end{array}$ \\
\hline 1 & Mentukuh & $\begin{array}{l}\text { Xanthophyllum amoenum } \\
\text { (Chodat) }\end{array}$ & Polygalaceae & 9.8 & 13.82 & 12.75 & 36.38 \\
\hline 2 & Ubah & Syzgium chloranthum (Duthie) & Myrtaceae & 9.8 & 15.95 & 8.5 & 34.26 \\
\hline 3 & Pemaris & Baccaurea odoratissima (Elm) & Phyllanthaceae & 5.88 & 7.44 & 18.82 & 32.15 \\
\hline 4 & Masang & Shorea parvifolis & Dipterocarpaceae & 5.88 & 6.38 & 12.34 & 24.61 \\
\hline 5 & Karank & Polyalthia flagellaris (Becc) & Annonaceae & 7.84 & 6.38 & 6.47 & 20.7 \\
\hline 6 & Jont & Lepisanthes tetraphylla (Vahl) & Sapindaceae & 5.88 & 5.31 & 6.88 & 18.08 \\
\hline 7 & Merabent & $\begin{array}{l}\text { Tristaniopsis merquensis } \\
\text { (Griff) }\end{array}$ & Myrtaceae & 3.92 & 5.31 & 3.23 & 12.47 \\
\hline 8 & Kerekep & Santiria oblongifolia (BI.) & Burseraceae & 3.92 & 4.25 & 3.84 & 12.02 \\
\hline 9 & Kembaas & $\begin{array}{l}\text { Ealeocarpus peduncusatus } \\
\text { (Wall) }\end{array}$ & Elaeocarpaceae & 3.92 & 4.25 & 0.4 & 8.58 \\
\hline 10 & Umbun & $\begin{array}{l}\text { Gymnostoma nobile } \\
\text { (Whitmore) }\end{array}$ & Casuarinaceae & 1.96 & 3.19 & 2.42 & 7.58 \\
\hline
\end{tabular}

Table 6. Analisis Vegetasi Tingkat Tiang (Pole level vegetation analysis)

\begin{tabular}{|c|c|c|c|c|c|c|c|}
\hline No & Nama lokal & Nama ilmiah & Family & $\begin{array}{l}\text { FR } \\
(\%)\end{array}$ & $\begin{array}{l}\text { KR } \\
(\%) \\
\end{array}$ & $\begin{array}{l}\text { DR } \\
(\%)\end{array}$ & $\begin{array}{l}\text { INP } \\
(\%)\end{array}$ \\
\hline 1 & Jont & Lepisanthes tetraphylla (Vahl) & Sapindaceae & 11.11 & 12.90 & 14 & 38.01 \\
\hline 2 & Ubah & Syzgium chloranthum (Duthie) & Myrtaceae & 11.11 & 9.67 & 12 & 32.78 \\
\hline 3 & Salam & Syzyqium polyanthum (Wight) & Myrtaceae & 11.11 & 9.67 & 8 & 28.78 \\
\hline 4 & Mentukuh & $\begin{array}{l}\text { Xanthophyllum amoenum } \\
\text { (Chodat) }\end{array}$ & Polygalaceae & 7.40 & 9.67 & 10 & 27.08 \\
\hline 5 & Kera & Saurauia glabra (Merr) & Actin & 7.40 & 9.67 & 10 & 27.08 \\
\hline 6 & Melinjo & Gnetum gnemon (L.) & Gnetace & 7.40 & 9.67 & 8 & 25.08 \\
\hline 7 & Karank & Polyalthia flagellaris (Becc) & Annona & 7.40 & 6.45 & 10 & 23.85 \\
\hline 8 & $\begin{array}{l}\text { Jambu } \\
\text { monyet }\end{array}$ & Bellucia pentamera (Naudin) & Melastomataceae & 7.40 & 6.45 & 6 & 19.85 \\
\hline 9 & Tebodou & Arto & Mo & 7.40 & 6.45 & 6 & 19.85 \\
\hline 10 & Kembaas & $\begin{array}{l}\text { Ealeocarpus peduncusatus } \\
\text { (Wall.ex) }\end{array}$ & Elaeocarpaceae & 3.70 & 3.22 & 2 & 8.92 \\
\hline
\end{tabular}

Table 7. Analisis Vegetasi Tingkat Pancang (Sapling level vegetation analysis)

\begin{tabular}{clllccc}
\hline \multirow{2}{*}{ No } & \multirow{2}{*}{ Nama lokal } & \multicolumn{1}{c}{ Nama ilmiah } & Family & $\begin{array}{c}\text { FR } \\
(\boldsymbol{\%})\end{array}$ & $\begin{array}{c}\text { KR } \\
(\boldsymbol{\%})\end{array}$ & $\begin{array}{c}\text { INP } \\
(\boldsymbol{\%})\end{array}$ \\
\hline 1 & Ubah & Syzgium chloranthum (Duthie) & Myrtaceae & 22.72 & 23.07 & 45.80 \\
2 & Mentukuh & Xanthophyllum amoenum (Chodat) & Polygalaceae & 18.18 & 19.23 & 37.41 \\
3 & Jambu monyet & Bellucia pentamera (Naudin) & Melastomatacea & 9.09 & 11.53 & 20.62 \\
4 & Salam & Syzyqium polyanthum (Wight) & Myrtaceae & 9.09 & 11.53 & 20.62 \\
5 & Pemaris & Baccaurea odoratissima $($ Elm) & Phyllanthaceae & 9.09 & 7.69 & 16.78 \\
\hline
\end{tabular}


Table 8. Analisis Vegetasi Tingkat Semai (Seedling level vegetation analysis)

\begin{tabular}{clllccc}
\hline \multirow{2}{*}{ No } & \multirow{2}{*}{ Nama lokal } & \multicolumn{1}{c}{ Nama ilmiah } & Family & $\begin{array}{c}\text { FR } \\
(\mathbf{\%})\end{array}$ & $\begin{array}{c}\text { KR } \\
(\mathbf{\%})\end{array}$ & $\begin{array}{c}\text { INP } \\
(\mathbf{\%})\end{array}$ \\
\hline 1 & Jambu monyet & Bellucia pentamera (Naudin) & Melastomataceae & 27.77 & 23.80 & 51.58 \\
2 & Tebodou & Artocarpus integer (Thunb) & Moraceae & 11.11 & 19.04 & 30.15 \\
3 & Salam & Syzyqium polyanthum (Wight) & Myrtaceae & 11.11 & 14.28 & 25.39 \\
4 & Mentukuh & Xanthophyllum amoenum (Chodat) & Polygalaceae & 11.11 & 9.52 & 20.63 \\
5 & Ubah & Syzgium chloranthum (Duthie) & Myrtaceae & 11.11 & 9.52 & 20.63 \\
\hline
\end{tabular}

Tabel diatas menunjukan pada tingkat pohon dan tiang diambil sepuluh jenis dari INP yang tertinggi sedangkan untuk tingkat pancang dan semai diambil lima INP tertinggi. Berdasarkan hasil inventarisasi untuk tingkat pohon ditemukan 23 jenis dengan total 94 individu, didominasi oleh Xanthophyllum amoenum (Chodat) dari family Polygalaceae dengan INP yaitu $36.38 \%$ dan Syzgium chloranthum (Duthie) dari family Myrtaceae 34,26\% (tabel 5). Indeks Nilai Penting Xanthophyllum amoenum (Chodat) lebih tinggi dari jenis lainnya dikarenakan jenis ini mendominasi pada semua petak dan memiliki diamater pohon lebih besar. Kondisi vegetasi di lokasi pengamatan merupakan daerah yang penutupan tajuknya masih rapat.

Xanthophyllum amoenum (Chodat) juga merupakan salah satu pohon yang disukai oleh kelulut sebagai tempat bersarang karena ukuran pohon yang berdiameter besar dan tajuk yang rimbun sehingga disukai oleh kelulut, Menurut Iqbal et al (2016) lebah Trigona spp lebih cenderung menempati pohon yang berukuran besar karena adanya naungan tajuk yang rimbun, tersedianya iklim mikro (microclimate) yang lebih sesuai dengan kehidupan Trigona spp terutama suhu dan kelembaban udara yang lebih stabil pada pohon besar serta tersedianya sumber pakan alami di daerah sekitarnya. Tingkat tiang didominasi oleh Lepisanthes tetraphylla (Vahl) $38,01 \%$, tingkat pancang didominasi oleh Syzgium chloranthum (Duthie) $45,80 \%$, dan tingkat semai didominasi oleh Bellucia pentamera (Naudin) $51,58 \%$.

\section{Sumber Pakan Lebah Kelulut}

Identifikasi sumber pakan kelulut pada lokasi pengamatan dilakukan dengan pengamatan secara langsung dan wawancara dengan warga setempat. Hasil pengamatan dan wawancara bisa dilihat pada tabel 7 . 
Tabel 9. Tumbuhan Pakan Lebah Kelulut Dalam Petak Pengamatan (Feed plants kelulut bees in the observation plot)

\begin{tabular}{llllc}
\hline No & Nama lokal & \multicolumn{1}{c}{ Nama ilmiah } & \multicolumn{1}{c}{ Family } & $\begin{array}{c}\text { Bagian yang } \\
\text { dimakan }\end{array}$ \\
\hline 1 & Ubah & Syzygium chloranthum (Duthie) & Myrtaceae & Bunga \\
2 & Jambu monyet & Bellucia pentamera (Naudin) & Melastomataceae & Bunga \\
3 & Meranti bunga & Shorea leprosula (Miq) & Dipterocarpacea & Bunga \\
4 & Merabent & Tristaniopsis merquensis $($ Griff) & Myrtaceae & Bunga \\
5 & Jont & Lepisanthes tetraphylla (Vahl) & Sapindaceae & Bunga \\
6 & Mentukuh & Xanthophyllum amoenum $($ Chodat) & Polygalaceae & Bunga \\
7 & Kandis & Garcinia parvifolia (Miq.) & Clusiaceae & Bunga \\
8 & Salam & Syzyqium polyanthum (Wight) & Myrtaceae & Bunga \\
9 & Pemaris & Baccaurea odoratissima $($ Elm) & Phyllanthaceae & Bunga \\
10 & Masang & Shorea parvifolis & Dipterocarpaceae & Bunga \\
11 & Bengkirai & Hopea beccariana (Burck) & Dipterocarpaceae & Bunga \\
12 & Karank & Polyalthia flagellaris (Becc) & Annonaceae & Bunga \\
13 & Jangkang & Xylopia malayana & Annonaceae & Bunga \\
14 & Medang & Litsea sp & Lauraceae & Bunga \\
15 & Kerekep & Santiria oblongifolia (BI.) & Burseraceae & Bunga \\
\hline
\end{tabular}

Tumbuhan pakan kelulut pada tabel 7 merupakan pohon penghasil bunga dan buah yang diduga sebagai penyedia sumber pakan dari lebah kelulut pada lokasi pengamatan. Jenis yang paling banyak ditemukan pada petak pengamatan yaitu family Myrtaceae yang merupakan suku jambu - jambuan, pada saat pengamatan pohon yang ditemukan berbunga adalah Syzgium chloranthum (Duthie), Lepisanthes tetraphylla (Vahl), dan Tristaniopsis merquensis (Griff). Pada lokasi pengamatan kelulut susah dijumpai dikarenakan pohon penghasil pakannya yang tinggi - tinggi sehinga susah melakukan pengamatan secara langsung, terlebih lagi ukuran kelulut yang kecil susah untuk diamati.

Tabel 10. Tumbuhan Pakan Lebah Kelulut Luar Petak Pengamatan (Feed plants kelulut bees outside of the plot of observation)

\begin{tabular}{llllc}
\hline No & Nama lokal & \multicolumn{1}{c}{ Nama ilmiah } & \multicolumn{1}{c}{ Family } & $\begin{array}{c}\text { Bagian yang } \\
\text { dimakan }\end{array}$ \\
\hline 1 & Kelapa & Cocos nucifera L. & Arecaceae & Bunga \\
2 & Durian & Durio zibethinus & Malvaceae & Bunga \\
3 & Rembutan & Nephelium lappaceum L. & Sapindaceae & Bunga \\
4 & Langsat & Lansium parasiticum & Meliaceae & Bunga \\
5 & Jambu air & Syzygium aqueum & Myrtaceae & Bunga \\
6 & Mangga & Mangifera indica L. & Anacardiaceae & Bunga \\
7 & Kakao & Theobroma cacao L. & Malvaceae & Bunga \\
8 & Alpukat & Persea Americana Mill. & Lauraceae & Bunga \\
9 & Terong & Solanum melongena L. & Solanaceae & Bunga \\
10 & Kacang & Vigna unguiculate sesquipedalis (L.) & Fabaceae & Bunga \\
& Panjang & Verdc & & Bunga \\
11 & Pepaya & Carica papaya L. & Caricaceae & Bunga \\
\hline 12 & Jagung & Zea mays spp. Mays L. & Poaceae & \\
\hline
\end{tabular}


Tumbuhan pakan kelulut diluar petak pengamatan banyak ditemukan di tumbuhan yang ditanam oleh warga sekitar yang bekerja sebagai petani, mereka mengatakan bahwa pada saat bekerja sering menjumpai kelulut hingap di bunga tanaman yang ditanam oleh mereka seperti sayur - sayuran, pohon penghasil buah (tabel 8).

Kelulut mencari nektar (sari bunga) untuk menghasilkan madu, nektar merupakan cairan manis kaya dengan gula yang diproduksi bunga dari tumbuhan sewaktu bunga mekar untuk menarik kedatangan hewan penyerbuk salah satunya kelulut, selain menghasilkan madu kelulut juga menghasilkan bee pollen (serbuk sari lebah) yang berasal dari gabungan serbuk sari tanaman yang dikumpulkan lebah serta nektar tanaman dan air liur lebah, ketiga bahan membentuk butiran halus yang disimpan di dalam kantung kaki lebah (Sihombing, 2005). Pada waktu matahari terbit sampai pukul 08:00 bunga banyak yang mengeluarkan nektar sehingga pada waktu tersebut terlihat banyak lebah yang mencari nektar, sedangkan pada siang hari yang panas nektar sudah tidak ada karena menguap, sehingga lebah lebih banyak mencari polen, dan mulai mencari lagi dari pukul 17:00 sampai menjelang malam.

\section{KESIMPULAN}

Jenis habitat tempat bersarangnya kelulut teridentifikasi yaitu di pohon hidup 52\%, pohon mati $20 \%$ dan tanah $28 \%$. Iklim mikro suhu rerata harian yaitu $28,81^{\circ} \mathrm{C}$, kelembaban udara 83,06
$\% \mathrm{RH}$, dan intensitas cahaya 583,76\%. Pengamatan edafis diketahui jenis tanah yaitu Podsolik Merah - Kuning (PMK) dengan $\mathrm{pH}$ rerata 4,4 , suhu tanah rerata $26,6 \mathrm{C}^{\circ}$, kelembaban tanah rerata $27,4 \%$ RH. Pengamatan fisiografis ketinggian tempat $\pm 360 \mathrm{~m} \mathrm{dpl}$. Analisis vegetasi Pada tingkat pohon didominasi oleh Xanthophyllum amoenum (Chodat) $36.38 \%$, Tingkat tiang didominasi oleh Lepisanthes tetraphylla (Vahl) 38,01\%, tingkat pancang didominasi oleh Syzgium chloranthum (Duthie) 45,80\%, dan tingkat semai didominasi oleh Bellucia pentamera (Naudin) 51,58\%.

Sumber pakan pada lokasi pengamatan didominasi family Myrtaceae dan Dipterocarpaceae, sedangkan diluar petak pengamatan sumber pakan kelulut didominasi oleh tumbuhan yang ditanam oleh petani seperti Cocos nucifera L., Durio zibethinus, Nephelium lappaceum L., Syzygium aqueum, Solanum melongena L., dll

Jenis lebah kelulut yang teridentifikasi di Kawasan Cagar Alam Gunung Niut, Dusun Dawar, Desa Pisak, Kecamatan Tujuh Belas, Kabupaten Bengkayang ada lima yaitu : Heterotrigona itama, Tetragonula laeviceps, Geniotrigona thoracica, Tetragonula carbonaria dan Tetragonula testaceitarisis dengan family Apidae.

\section{SARAN}

Hasil penelitian ini diharapkan mampu memberikan informasi kepada masyarakat sekitar agar dapat menjaga habitat dan sumber pakan kelulut sesuai dengan kondisi alaminya, serta perlu 
dilakukan penelitian tentang bagaimana cara pembudidayaan lebah kelulut untuk dapat memaksimalkan hasil madu dan untung dalam segi ekonomi bagi masyarakat sekitar tanpa merusak habitat alaminya.

\section{DAFTAR PUSTAKA}

Angraini AD. 2006. Potensi Lebah Propolis Trigona spp. sebagai Bahan Anti bakteri (Skripsi).Institut Pertanian Bogor. Tidak dipublikasikan.

Banowu H. 2016. Studi Perkembangan Koloni Dan Produksi Lebah Trigona sp. Dari Posisi Stup Yang Berbeda. Fakultas Kehutanan Dan Ilmu Lingkungan Universitas Halu Oleo

Bankova V. 2005. Recent Strends and Important Developments in Propolis Research. eCAM2(1): 2932.

Francoy TM, Silva RAO, Nunes-Silva P, Menezes $\mathrm{C}$ and ImperatrizFonseca VL. 2009. Gender Identification of Five Genera of Stingless Bees (Apidae, Meliponini) Based on Wing Morphology. Genet. Mol. Res. 8(1): 207-214.

Iqbal M, Defri Y, Budiani ES. 2016. Karakteristik Habitat Trigona spp. Di Hutan Larangan Adat Desa Rumbio Kabupaten Kampar. Jom Faperta UR Vol 3 No 2

Michener CD. 2007. The Bees of the World. 2nd editions. The Johns Hopkins University Press, Baltimore, USA. $972 \mathrm{~h}$.

Riendriasari SD. 2013. Budidaya Lebah Madu Trigona sp. Mudah dan Murah.Makalah Seminar Alih Teknologi "Budidaya Lebah Madu
Trigona sp”. Balai Teknologi Hasil Hutan Bukan Kayu. Mataram.

Roubik DW. 2006. Stingless Bee Nesting Biology. Apidologie. 37: 124-143

Sforcin JM, Bankova V. 2011. Propolis: Is there a potential for the development of new drugs? JE thnopharmacol 133(2): 253-260.

Sihombing DTH. 2005. Ilmu Ternak Lebah Madu. Gadja Mada University Press, Yogyakarta.

Syafrizal AA, Bratawinata M, Sila D, Marji. 2012. Jenis Lebah Kelulut (Trigona spp) Di Hutan Pendidikan Lempak. Fakultas MIPA Universitas Mulawarman Samarinda, Fakultas Kehutanan Universitas Mulawarman Samarinda, Fakultas Kehutanan Universitas Hasanudin Makasar.

Syafrizal, Tarigan D, Yusuf R. 2014. Keragaman dan Habitat Lebah Trigona spp pada Hutan Sekunder Tropis Basah di Hutan Pendidikan Lempake, Samarinda, Kalimantan Timur. Jurnal Teknologi Pertanian 9(1):34-38, 3 